1988

\title{
International Law and Terrorism: Age-Old Problems, Different Targets
}

Sharon A. Williams

Osgoode Hall Law School of York University, sawilliams@osgoode.yorku.ca

Source Publication:

Canadian Yearbook of International Law. Volume 26 (1988), p. 87-118.

Follow this and additional works at: https://digitalcommons.osgoode.yorku.ca/scholarly_works

Part of the Comparative and Foreign Law Commons, International Law Commons, and the National Security Law Commons

(c) $($ ) $\Theta \Theta$

This work is licensed under a Creative Commons Attribution-Noncommercial-No Derivative Works 4.0 License.

\section{Recommended Citation}

Williams, Sharon A. "International Law and Terrorism: Age-Old Problems, Different Targets." Canadian Yearbook of International Law 26 (1988): 87-118.

This Article is brought to you for free and open access by the Faculty Scholarship at Osgoode Digital Commons. It has been accepted for inclusion in Articles \& Book Chapters by an authorized administrator of Osgoode Digital Commons. 


\title{
International Law and Terrorism: Age-Old Problems, Different Targets
}

\author{
SHARON A. WILLIAMS*
}

\section{INTRODUCTION}

TT IS A FAGT AND scourge of international life that international 1 terrorism knows no boundaries. A terrorist organization based in one state may wreak havoc within the domain of other states by a wide variety of methods. Over the last two and a half decades in particular the international community has witnessed an acceleration of attacks against civilian aircraft and civilian aviation facilities, attacks on diplomats and other so-called "internationally protected persons," and hostage-taking.

The spate of attacks against civil aviation prompted the adoption by member states of the International Civil Aviation Organization (ICAO) of the Tokyo, ${ }^{1}$ Hague $^{2}$ and Montreal ${ }^{3}$ Conventions. Likewise, attacks on internationally protected persons, including diplomats, and hostage-taking gave the impetus for the $1974^{4}$ and $1979^{5}$ international conventions on those subjects.

* LL.B., LL.M., D. Jur., Associate Professor of Law, Osgoode Hall Law School, York University, Ontario.

1 Tokyo Convention on Offences and Certain Other Acts on Aircraft, 1963, 704 UNTS 2 1 9, r 970, Can. T. Ser. No. 5, hereinafter "Tokyo Convention."

2 Hague Convention for the Unlawful Seizure of Aircraft, 1970, 860 UNTS 105, 1972, Can. T. Ser. No. 23, hereinafter "Hague Convention."

3 Mont-nal Convention for the Suppression of Unlawful Acts Against the Safety of Civil Aviation, 1971, 974 UNTS I 77, 1973 Can. T. Ser. No. 23, hereinafter "Montreal Convention."

4 Convention on the Prevention and Punishment of Crimes Against Internationally Protected Persons including Diplomatic Agents, 1974 UNGA Res. 3166 (XXVII), 28 UN GADR Supp. (No. 30), 147, UN Doc. A/9030, reprinted in (1974) I 3 Int'l Leg. Mat. 41, hereinafter "IPP Convention."

6 The Convention Against the Taking of Hostages, 1979, (1979) 18 Int'1 Leg. Mat. 1456, hereinafter "Hostages Convention." 
This piecemeal approach to dealing with terrorism was taken because there was no chance of success in framing a single comprehensive treaty dealing with all types of acts. ${ }^{6}$ It was thought that this fragmented and incremental approach would encourage many more ratifications of most, if not all, the conventions.

Several recent incidents have brought home the realization that much remains to be done in the fight not simply to combat but to eradicate international terrorism. The attacks on the passenger terminals in the Rome and Vienna airports in 1985 , the hijacking of the Italian cruise ship, the Achille Lauro, in 1985 , the aerial destruction of the Air India jumbo jet en route from Canada to India in 1985 and the Pan Am flight from London to New York in 1988, and the various hostage-taking incidents in Lebanon bring home in stark terms the fact that there is a great deal to be done. The perceived problems are at least threefold: first, a lack of treaty obligations requiring extradition or prosecution in certain situations not covered by the existing scheme of conventions; second, third party frustration of the existing conventions; and third, the impact of the ideologically motivated offender seeking publicity for a cause on the treaty approach.

The real fear is that terrorists can use the lacunae in this area of international law to attack certain targets and go free because there will be enough safe-haven states to give them asylum and also enough states that, even though not condoning the acts, will be incapable, under their own domestic criminal laws, of either prosecuting them because of lack of pertinent bases of jurisdiction over the offence, or extraditing them because of the political offence exception to extration.

In this article the following issues of current significance will be considered : first, should the eradication of the so-called "root causes" of terrorism take precedence over conventions to suppress or punish terrorists; second, the gaps that have been found in the existing

- Note the 1937 Convention on Terrorism, Hudson, International Legislation, vol. 7 , at 862 , which is the only global comprehensive treaty on terrorism. The Convention never came into force as there was a failure on the part of the states that signed to ratify. In fact only India did so. See also the 1977 European Convention on the Suppression of Terrorism, 1977 E.T.S. No. 97, which contains a composite approach following along the lines of the 1937 Convention. This Convention has been looked at as a major breakthrough, as it covers terrorism in almost all its aspects. It demonstrates that the states belonging to the Council of Europe, on account of their regional similarities, are capable, at least in theory, of taking a more comprehensive tack. See also the European Convention on Extradition, 1957 E.T.S. No. 98. 
multilateral convention approach to international terrorism, and third, the steps that have been taken recently by the concerned specialized agencies of the United Nations to remedy the situation.

\section{Order of Priority: "Root Causes" or New Conventions}

As long as certain peoples view themselves as politically oppressed and subjected to constant affronts to their human dignity, can there be an end to violence to achieve their goals, whether they be political and civil rights, a new government, territory, and so forth? Until the deep-rooted causes of such violence are addressed, will the terror threat always remain? It has been said, time and time again, that terrorists are made, not born and that until, for example, the refugee camps in the Gaza and West Bank are closed and the people granted full human rights and freedoms as first class citizens of a country whether in Israel, Arab states, or a Palestinian state; until the regime of apartheid is decimated in Southern Africa; until a peaceful solution between the Christians, the Shiite Moslems, the Sunni Moslems, and the Druse is found in Lebanon, the bloodshed and horror will continue.

At first blush, an optimist would say "yes," the international community can end the hijackings, hostage-takings, bombings, and other terrorist attacks by working urgently to solve the causes of these acts. True, if the serious disorders and struggles for human dignity and self-determination were to be dealt with adequately, then perhaps a great proportion of the violence would cease. However, the optimist should also be realistic. Even if the problems appeared to be solved in one global area, this is not to say that other locales might not develop new tensions. The process of cause-solving would have necessarily to be ongoing. Also, even with dignity and territory achieved by the "peoples" concerned, there may well be disaffected splinter groups that might continue their struggle against the new government and state. For some the tactics of intimidation by violence may have become a way of life.

Obviously, the root causes must be stamped out - but it may take time. These problems have been with us for decades and the solutions are not going to appear like rabbits out of a conjurer's top hat. All states must seek both inside and outside the United Nations to promote an early end to the suffering and misery of so many people who are denied in many respects the most basic of human rights. However, while working to cure the root causes, it is imperative that the world 
community take the international convention route to deter and if not to prosecute and punish international terror-violence ${ }^{7}$ against internationally protected targets, as well as other measures such as increased security at airports, harbours, and embassies, and continued mutual assistance and exchange of data.

Acts of violence should not be justified or condemned on the basis of a subjective evaluation of the cause they were taken to promote. To do so leads to interminable problems of distinction. No matter how justifiable the political cause, certain acts are not acceptable at international law. Attacks or threats to attack protected targets such as innocent civilians, internationally protected persons, civil aviation, and arguably other entities removed from government are to be condemned without reservation. The unprecedented acceptance by all member states of the United Nations in 1985 of the resolution declaring that all methods of terrorism are to be condemned, regardless of where they occur and who the perpetrators are, supports this argument. ${ }^{8}$ This resolution adopted by consensus indicates that states are conscious of the inherent dangers in terrorism to all. None are immune. The Canadian delegate to the Sixth Committee of the United Nations General Assembly declared in 1987 that "it is essential to bear in mind the importance of this achievement and to hold fast to the unconditional condemnation ... in the General Assembly against terrorism."

Some states have argued that a definition of terrorism should be produced that would differentiate it from national liberation struggles and the use of force to that end. ${ }^{10}$ It must be questioned seriously

7 See R. Friedlander, Terrorism: Documents of International and National Control (3 vols., 1979). There have been countless articles written on this subject generally as well as on its specific aspects. This is illustrated by the comments contained in M. G. Bassiouni (ed.), Legal Responses to International Terrorism: U.S. Procedural Aspects (1988). In particular, see therein M. C. Bassiouni, "A Policy-Oriented Inquiry into the Different Forms and Manifestations of 'International Terrorism'," at xv.

8 UNGA Res. 40/61, Dec. 9, 1985.

- P. Kirsch, Representative of Canada in the Sixth Committee, $42 n$ Session of the General Assembly, Statement of Oct. 2 1, 1987, at 2 (original in French). Note also the condemnation of terrorism made at the Venice Economic Summit on June 9, 1987 , by the seven industrialized states and transmitted to the General Assembly and Security Council of the United Nations: see UN Docs. $A / 42 / 336$ and $S / 189$ is.

10 See the proposal by the Syrian Arab Republic to convene an international conference to do this: UN Doc. A/42/193. Note the support for this by Democratic Yemen, Algeria, and Kuwait on behalf of the Group of Arab states: UN Doc. A/42/193/ Add. I-3. 
what this would in reality achieve. The Canadian delegation was of the view that the answer was nothing, ${ }^{11}$ that to return to debate the root causes and distinctions between illegal acts constituting terrorism as opposed to justifiable acts of national liberation would be to take steps backward and lose a unity of purpose by jeopardizing the agreement on objectives gained over the years. ${ }^{12}$ It would almost certainly be impossible to get agreement on a general definition of terrorism as it has been in the past. It is only by defining the criminality of conduct without reference to political motivation that agreement is possible between states of diverse ideological and sympathetic persuasions.

The Mulmilateral Approach to Dealing with International TERRorism: Stopping the Gaps

As the modes of international terrorism change, so must the response of the international community. As was indicated at the outset, no matter how morally or legally justifiable the cause, certain targets must remain protected; this is vital to the self-preservation of all humankind. The key international conventions until 1988 dealt with hijacking, ${ }^{13}$ other unlawful acts against the safety of civil aviation, ${ }^{14}$ attacks on internationally protected persons including diplomatic agents, ${ }^{15}$ hostage-taking, ${ }^{16}$ and offences against nuclear material. ${ }^{17}$ The cornerstone of these conventions is ( $I$ ) to ensure that as many states as possible have a basis of jurisdiction over the offences, including a basis founded on presence within the territory of the prosecuting state, which can be viewed as a contemporary version of the universal principle of jurisdiction; and (2) to provide for an obligation on a state to either extradite to another state with jurisdiction or to submit to its own authorities the case for the purposes of prosecution in a serious fashion (aut dedere, aut judicare). Political motivation does not operate to thwart the efficacy of these conventions and, even if the political nature of the offence or the alleged

11 Supra note 9, at 6. Many other delegations took the same view and twenty states together with Canada introduced draft resolution A/C.6/42/L.2, which reaffirms and is largely based on the earlier resolution $40 / 6 \mathrm{r}$.

12 Ibid., 7.

13 Hague Convention on the Unlawful Seizure of Aircraft, 1970.

14 Montreal Convention, 1971.

15 IPP Convention, 1974.

16 Hostages Convention, 979.

17 The Convention on the Physical Protection of Nuclear Material, 1979, reprinted in (1979), Int'l Leg. Mat. 1419. 
political motivation of the requesting state is the ground for refusal, the obligation to submit the case for the purpose of prosecution remains. It is thus not a case of political asylum beginning where extradition fails.

However, it is only in these fairly restricted areas that these obligations exist. A smart international terrorist versed in the intricacies of international co-operation in criminal matters until 1988 would know that the obligations did not cover ships, airport passenger terminals, platforms fastened to the continental shelf, or the deep seabed. Today intercontinental trains and buses are still not dealt with, and perhaps futuristically space shuttles and the like and their on-site space stations are not protected by the dual obligation of aut dedere, aut judicare (extradite or prosecute).

This is not the appropriate time to analyze again the "old" conventions already on the international books, but rather to look afresh at the newest attempts by two specialized agencies of the United Nations to contribute to the suppression, or rather eradication, of this scourge of the twentieth century.

THE INTERNATIONAL GIVIL AVIATION ORGANIZATION AND THE I 988 PROTOCOL TO THE MONTREAL CONVENTION, I97I

The Tokyo, Hague, and Montreal Conventions were the initial steps taken by the international community to deal with the spate of terrorism in the air in the I960s and early I97os, but their step-bystep approach clearly left serious gaps, such as terrorist violence at airports serving civil aviation. ${ }^{18}$ The casual observer might question the importance of these initial steps but, as primitive as it may seem, the value of the international conventional obligation to extradite or prosecute can act as a deterrent in many (if not all) cases and at least is a symbolic condemnation by those states participating through ratification or accession. The "gaps" are not so covered and the political offence exception could, unless restricted by bilateral extradition treaties, ${ }^{19}$ operate with significant success, and detriment to international peace and security.

18 For a recent summation of the work of ICAO in the area before adoption of the 1988 Convention under consideration here, see the article by the late G. F. FitzGerald, "Aviation, Terrorism and the International Civil Aviation Organization," (1987) 25 Canadian Yearbook of International Law 219.

19 See, for example, the 1988 Protocol to the Extradition Treaty between Canada and the United States of America, 1976 Can. T.S. No. 3. This Protocol, which is not yet in force, will amend the treaty by limiting the political offence 
The ${ }_{19} 85$ Vienna $^{20}$ and Rome ${ }^{21}$ airport terrorist assault incidents, followed by the Frankfurt attack in 1985 , presented the International Civil Aviation Organization (ICAO) with a state of necessity for action. ${ }^{22}$ No longer were incidents connected solely with aircraft in flight $^{23}$ or in service. ${ }^{24}$ Innocent travellers in airport facilities were being involved in random and indiscriminate acts. From its inception the ICAO has been at the forefront of the attempt to curb the international terrorist threat. This specialized agency of the United Nations has the experience and expertise to understand the diplomatic pitfalls in producing any multilateral treaty and also is aware of the importance of its role in protecting the safety of civil aviation, its facilities, and consequent individuals involved.

Airports can be viewed as a type of international crossroads. In the busiest of the world's airports thousands of passengers are handled every day. Aircraft flights arrive and depart from all parts of the world. Clearly, they present an extremely tempting target for terrorist action. The state that is the scene of the terror-violence may in no way be directly involved in the dispute between the terrorists and another state.

At the 26th Session of the Assembly of ICAO in r 986 , Canada and several other states ${ }^{25}$ recommended that the Assembly include

exception to the greatest extent. See Art. 4. Similarly, see the new extradition treaty of 1987 between Canada and India which in Art. 5 contains a similar restriction.

20 The $\mathrm{El}$ Al check-in counter was the target and two passengers were killed and 39 wounded.

21 This incident occurred on Dec. 27, 1985, in front of the El Al check-in counter. The terrorists opened fire with guns and grenades and 15 people were killed and 77 wounded.

22 The following non-exhaustive list of airport violence reinforces the problem: 1 973, 3 incidents (Calvi; Rome; Athens) ; 1 974, 2 incidents (Heathrow; Los Angeles); 1975, 2 incidents (Orly; La Guardia); 1976, 4 incidents (Tel Aviv; Delhi; Beirut; Ajaccio); 1979, 2 incidents (Frankfurt) ; 1981, 2 incidents (Collingwood; Cairo); 1982, 2 incidents (Miami; Los Angeles); r 983 , 2 incidents (Narita; Orly) ; 1984,2 incidents (Kabul; Beirut) ; 1985,4 incidents (Frankfurt; Vienna; Rome; Narita). Note the European Conference of Ministers Responsible for Combatting Terrorism, Strasbourg, Nov. 4-5, 1986, Rec. 1024 (1986) Doc. 55 I8 on the European Response to Terrorism.

23 Montreal Convention, Art. 2 (a).

24 Montreal Convention, Art. 2(b).

25 Australia, Austria, Belgium, Chile, Columbia, Denmark, France, Finland, Greece, Iceland, India, Ireland, Italy, Luxembourg, Mexico, Norway, The Netherlands, New Zealand, Philippines, Portugal, Saudi Arabia, Sweden, Switzerland, Turkey, and Uganda. 
as a high priority, in the program of work of its legal committee, the matter of a possible agreement on the suppression of unlawful acts of violence at airports serving international air transportation. ${ }^{26}$ States generally, regardless of their political sympathies, have an undeniable interest in the safety of their own airports and passengers and employees therein and also in the fate of their citizens while they sojourn abroad. In terms of sheer numbers, the variety of nationalities, and hence widespread publicity, airports used for international air transportation offer an attractive target for attack. The initiative taken by Canada and the other states was aimed at preventing unlawful acts at such airports through enhanced co-operation, but also at ensuring that the perpetrators, if able to do their deadly deeds, would not go unprosecuted and, if found guilty, would be punished.

The time was clearly ripe for a new international initiative. Some ${ }^{27}$ had doubted whether ICAO would be capable of it, on account of the consultative status at ICAO of the Palestine Liberation Organization (PLO). In the event, this pessimism, at least at the diplomatic conference level, was not warranted. The matter was referred by the Executive Committee to the Legal Committee and in that Committee, the recommendation was supported by all delegations; it was agreed that the highest priority be accorded to this matter. ${ }^{28}$ This recommendation by the Legal Committee was also the subject of a resolution adopted unanimously by the Assembly of ICAO, ${ }^{29}$ which called upon the Council of ICAO to include the subject of such a draft instrument in the work program of the Legal Committee, as a subject of the highest priority, and to convene as early as possible in r 987 a meeting of the Legal Committee to draft an instrument with a view to adoption at a diplomatic conference as soon as was practicable, preferably before the end of 1987 .

At the behest of the Council of ICAO a Special Sub-Committee of the Legal Committee was convened ${ }^{30}$ in early January 1987 to implement the Assembly's resolution. It considered the subject of the resolu-

${ }^{26}$ Doc. A26-WP/41, EX/9, 14/7/86.

${ }^{27}$ E.g., see Green, L. C., “Terrorism and International Law,” Research Report, Institute of Jewish Affairs, in Association with the World Jewish Congress ( I 98 I), II.

28 See ICAO Doc. 9502-LC/ 86 ( ( 987 ), at 4-I.

29 Res. A26-4. See ibid., at 1 and $4^{-1}$.

30 Ibid. The Sub-Committee was established by the Chairman of the Legal Committee under Rule 12 (b) of the Rules of Procedure of the ICAO Legal Committee. See ibid., 4-1. 
tion on the basis of a study and draft text prepared by the Rapporteur. ${ }^{31}$ The Sub-Committee itself prepared a draft text for further consideration by the Legal Committee. Under the rules of procedure of ICAO, a working group was created to consider the text prepared by the Sub-Committee in the light of state views, to attempt to narrow the scope of differences that remained, and to prepare a text or texts for further consideration by the Legal Committee. ${ }^{32}$ The Canadian Chairman of the Working Group presented to the Committee the text of the Preamble and the Committee approved a draft text.

The result was not that far off the timing indicated in the Assembly's resolution. On February 24, 1988, a Protocol to the Montreal Convention was adopted by consensus at a diplomatic conference. In general terms, it was agreed that the new instrument should not depart from the basic principles of the Hague and Montreal Conventions and it should seek only to supplement the Montreal Convention. For this reason, it was agreed that the new instrument should not take the form of a new convention but of a Protocol to the Montreal Convention of 197 I. It would not change the substantive parts of the earlier convention, but would be supplemental and add to the definitions of offences additional acts not addressed. ${ }^{33}$

The supplementary protocol route was the less controversial of the two options. To produce a new convention would have caused all the "old chestnuts" to resurface : exclusion or inclusion of self-determination units; treaties of asylum; the political offence exception; and the "anti-Entebbe" clause. ${ }^{34}$

The draft text approved by the Legal Committee and adopted by consensus by the diplomatic conference in February 1988 considered that unlawful acts of violence at airports serving civil aviation jeopardize the safety of persons and property at such airports and, inter alia, disturb the safe and orderly conduct of civil aviation for all countries. Article 2 ( I) of the 1988 Protocol provides that Article I of the Montreal Convention shall be followed by a new paragraph,

31 Dr. R. D. van Dam (The Netherlands) was appointed Rapporteur under Rule I 7 of the Rules of Procedure of the ICAO Legal Committee by the Chairman. Ibid.

32 Supra note 28, at 4-10.

33 See the Sub-Committee Report on the Development of an instrument for the Suppression of Unlawful Acts of Violence at Airports Serving International Civil Aviation, Montreal, January 1987, LC/SC-VIA, Part II, 5. Note also Art. I of the Protocol itself.

34 Supra note 28 , at 4-27. 
Article I ( I) bis. Article I ( I) $b^{3{ }^{35}}$ provides that any person commits an offence if he [or she] unlawfully and intentionally, using any device, substance, or weapon, acts violently against a person at an airport that serves civil aviation, which act causes or is likely to cause death or serious injury, or if that person destroys or seriously damages the facilities of an airport serving international civil aviation or aircraft not in service located thereon or disrupts the services of the said airport, if such an act is likely to endanger or endangers safety at that airport. Article 2(2) of the Protocol covers attempts to do the above. Article 3 of the Protocol states that the new Article 5(2) bis to follow Article 5 of the Convention will ensure jurisdiction over such offences and the obligation to extradite or prosecute.

In the context of its deliberations the Legal Committee decided and it was later accepted by the Assembly that the international element was vital for the applicability of the Protocol. Several delegations were of the view that this international element was to be found in the concept of the "airport serving international civil aviation." It was agreed by the Committee that the definition of that term should be based on fact, rather than on a matter of strict legal definition. ${ }^{36}$ It was noted that the existing Montreal Convention and Annexes did not contain a definition of "airport" or "international airport" or "airport serving international aviation" and it appeared that no difficulties of a practical nature had so far surfaced. A plain reading of Article 2 of the Protocol indicates that it will apply fairly widely to all acts of violence or destruction connected with an airport serving international civil aviation. It is not limited in scope but refers to facilities of such an airport or aircraft not in service. Facilities are not defined and it could be argued that it means facilities located inside and outside of the airport structure.

Concerning the new offence contained in new paragraph $\mathbf{I}$ bis to the Montreal Convention, the crucial element is that the act "endangers or is likely to endanger safety at that airport." The Rapporteur, Mr. van Dam of the Netherlands, in his draft text before the SubCommittee had proceeded also to define what was meant by this condition. His definition read as follows:

For the purpose of paragraph I bis, the safety of civil aviation shall be deemed to be endangered, if the offences contemplated in subparagraphs (a) and (b) of paragraph I bis of Article I are committed in an area of

35 Ibid., 4-27.

36 Ibid., 4-5. 
the airport where measures necessary in relation to the commencement or completion of an international journey by air are carried out, and cause or are likely to cause (grievous) injury or death or serious damage or destruction in that area. ${ }^{37}$

This definition caused controversy in the special Sub-Committee. One bone of contention was that the provision would set a presumption that would "hardly be acceptable" in the field of criminal law. ${ }^{38}$ Another criticism was that it would cover many acts that were unrelated to civil aviation and did not warrant international criminalization and subjection to the principle of aut dedere, aut judicare. The recurring example (for some unknown reason!) before the SubCommittee of an act that should be regarded as a "private"39 type of violence and not within the purview of the Protocol was that of a criminal offender attacking his mother-in-law in a critical area of an airport. Some members, however, argued that even such a case could result in danger to the safety of civil aviation if it was committed with certain types of weapons or explosives, as other innocent bystanders might be endangered and so too the operation of the airport. ${ }^{40}$ In the end the Sub-Committee agreed that motive should not be viewed as relevant but the only factor of weight should be "the objective effect," ${ }^{11}$ that of danger to international civil aviation.

One last comment is necessary on the subject of new paragraph 2 bis to Article 5 of the Montreal Convention concerning jurisdiction over the offence and extradition. The 1988 Protocol has a novel feature that is also restrictive as it stipulates that the state where an alleged offender is present shall take measures necessary to establish its jurisdiction over the offences where it does not extradite to the state where the offence was committed. It is not unusual to give priority to extradition where prosecution via jurisdiction on the universal basis is the sole alternative. All of the pre-existing anti-terrorist conventions are couched in such terms. However, the Protocol adds a twist; extradition is restricted to the state with the territorial basis of jurisdiction and does not provide for any other potential bases such as the active and passive nationality principles. The Sub-Committee had suggested that extradition should be referrable to any of the states

37 It would have been included as para. 2 bis to Art. 4 of the Montreal Convention. See supra note 33 , at 8.

38 Ibid., 9.

39 Ibid.

10 Ibid.

41 Ibid. 
mentioned in Article 5 ( $\mathrm{r}$ ) of the Montreal Convention..$^{42}$ The Legal Committee, however, was of the view that the bases contained therein comprising the state of registration of aircraft, against the state where the aircraft on which the offence was committed lands with the offender still on board, and the state of the principal place of business or permanent residence of an operator of a leased aircraft or on board of which an offence has occurred, had no relevance to the new offence contained in the Protocol. It was of the view that the state in whose territory the offence was perpetrated has the closest link with the crime and the most interest in initiating a prosecution. This is in keeping with the view of most common law jurisdictions that priority be given to the territorial basis of jurisdiction on account of the factors mentioned and also the location of evidence and witnesses.

It does not appear that there was any discussion of Article 5(3) of the Montreal Convention that provides that the Convention does not exclude any criminal jurisdiction exercised in accordance with national law. This would allow a number of other bases to operate under the 197 I Montreal Convention. The Protocol as adopted rules these out for Article I, paragraph I bis offences. The only states concerned are the state where the alleged offender (or criminal where an escapee) is found and the place where the offence occurred. The Committee noted that in this case, as opposed to other international terrorist offences covered by the multilateral conventions, there could not be competing claims for extradition as only one state has the prospect of making the request for it. On this account it is worth repeating that the Committee stressed the priority of extradition. ${ }^{43}$

Of the many contributions on this matter by various delegations it is worthwhile to single out the proposals of two states. The Netherlands in its proposal ${ }^{44}$ had an interesting concept that the state where the offender is found to be present is only obliged to prosecute where that state does not comply with an extradition request from the state with territorial jurisdiction. ${ }^{45}$ The Netherlands explained that jurisdiction to prosecute should not be imposed if an extradition request is not made. This proposal did not find favour with the Committee. It would have been a radical departure from the other existing Conventions, including most importantly the 1971 Montreal Con-

42 Supra note 28, at 4-18.

43 Ibid., 4-20.

44 ICAO Doc. LC/26-WP/4-6.

45 Supra note 28, at 4-I 9. 
vention. None of these makes prosecution contingent on an extradition request being made and being refused. The Netherlands stated that in relation to the earlier conventions its government had made reservations with respect to some of them in a similar vein to its proposal and that such a reservation might also be made with respect to the Protocol. The big question that presents itself is why The Netherlands felt the need to do this? It may be speculated that The Netherlands does not want to be burdened with a political and administrative "hot potato" when the offender is found there and no other state makes a request. As the then chairperson of the Working Group has noted recently, "the Dutch have traditionally been plagued by offenders being dropped off by planes or ships, on their territory, leaving them with all [the] obligations and none of the evidence connected with the case." 46

In the case of the Soviet Union the reasoning may have been quite different. ${ }^{47}$ The USSR proposal was to include a provision that preference in extradition should be given to the state in which the airport where the offence was committed, was located. This clearly ties in with the territorial approach and was probably just a reinforcement of the Soviet wish to have priority in prosecuting those committing offences against Soviet targets; in the negotiations leading to the earlier conventions the Soviet delegation had repeatedly requested compulsory extradition in such circumstances to the territorial state of registry of an aircraft. In this case, they were the most successful to date in attaining favourable wording.

The Soviet Union also made another very relevant point in its same proposal. ${ }^{48}$ It concerned airport security. As a practical matter airport security through sanitized security zones and ultra-trained personnel may be the answer from a deterrence point of view. The Soviet view was that the Protocol should include some provisions dealing with security and putting legal obligations on states to prevent violent acts at airports serving international civil aviation within their territory. Article Io( I) of the 197 I Montreal Convention provides that contracting states are obliged in accordance with international

46 Kirsch, "The I988 ICAO and IMO Conferences Against Terrorism and a Look at History: Will the Consensus Hold?," unpublished speech given in his capacity as Director, Legal Operations Division, Dept. of External Affairs, Canada, at a dinner meeting of the International Law Association, Ottawa Branch, May $18,1988$.

47 Supra note 28 , at 4-5.

48 Ibid., 4-5. 
and national law to take all practicable measures for the purpose of preventing crimes listed in Article I. The USSR determined that Article ro could be amended by the Protocol to include a specific obligation to provide for the presence of duly authorized and trained security personnel at airports as well as inspections and monitoring of these measures and the establishment of rules to prohibit and prevent unauthorized access of persons or of means of transport into controlled zones and other zones that are important for airport operations. ${ }^{49}$ This proposal was not accepted. One reason given was that it would require a definition of "controlled zone" at an airport and the Committee had already abandoned that task at an earlier stage of their deliberations. ${ }^{50}$

It is obvious that certain security measures over and above those regularly entertained could only ameliorate the present situation. To name but a few potential sources of problems: (I) baggage should not be capable of direct check-in from state $A$ to state $C$ where $A$ is the state of initial embarkation and $C$ the final destination, if a change of planes must occur in state $B$ and the passenger will be in transit. Lack of security in state A may allow a bag to be checked with explosives on timers that will not explode until the second leg of the journey on a different aircraft; (2) curbside baggage checks should be discontinued, as bags may be checked in this manner and the prospective passenger not board the plane; and (3) new hightech detection devices must be used to scan baggage to check for explosives. Passengers must also be conditioned to arrive earlier at airports and be prepared for intensive security.

For an airport to be made secure against terrorist attack, it must be seen much differently than it is today. It cannot be an open area; the procedures for security must be sophisticated and tight. It clearly is not conducive to the holiday atmosphere for tourists to see watchtowers, guard dogs, barbed wire, and so on, but these and other measures are warranted if they will deter terrorist acts. Perhaps entry points to airport terminals should be guarded; friends and relatives not allowed to enter, and lockers be a thing of the past; restaurants and other shopping facilities only be located beyond the second secured checkpoint. Once a passenger has handed in his or her ticket, been assigned a seat, and checked bags, perhaps there should be no ability to walk out of the terminal without investigation. There

49 Ibid., 28, 4-20-4-21.

so Ibid., 4-21. 
should be a rigid check that prospective passengers who checked the baggage are on the plane in question. While this will not thwart the suicidal terrorist, it may deter others more concerned with their own safety. Baggage must be matched to passengers at the gate before boarding and non-identified pieces put in a security zone. To detect the suicidal type of terrorist, the checked luggage must be searched again at this stage for certain types of chemical explosives. Of less obvious note, but equally serious nature, all other cargo and catering services and cleaning personnel would undergo the same treatment.

One might go even further and suggest that not only outgoing but incoming passengers and their baggage should go through the same procedures. Strict security should extend to all aircraft and ground staff. Far more security background investigations should take place, plus on the spot checks.

All these techniques would require technology and personnel. The result would be higher costs to air travellers passed through the airline industry. Without a doubt it would either mean delays or greatly increased time expenditures before a flight. The challenge is to protect all persons and facilities involved without going overboard in creating a pallisade structure. There must be a balance struck. As in all other debates on terrorism, if states react by turning their territories into fortresses and repress civil liberties as generally perceived, the terrorist forces will have achieved success.

A final question is who may sign, ratify, or accede to the Protocol. At the debate stage some delegations appeared to wish the participation of states that are not parties to the Montreal Convention of 197 I, in the Protocol of $1988 .{ }^{51}$ This would not have been desirable or practical. The accepted policy of ICAO, and even of the United Nations itself, is to encourage states to become parties to all the multilateral anti-terror violence conventions. Thus it would have been a reversal of policy to allow non-parties of the Montreal Convention, for reasons known only to themselves, to obligate themselves by the new Protocol alone. Article 5 of the Protocol as adopted provides in paragraph 2 that "Any State which is not a Contracting State to the Convention may ratify this Protocol if at the same time it ratifies or accedes to the Convention in accordance with Article 15 thereof." 52

ICAO with its proven track record was well-versed specifically in the area of aviation terrorism and more generally in the problems and

\footnotetext{
51 Ibid.

52 Emphasis added.
} 
pitfalls of diplomatic wrangling and horse-trading. The amendment, drafted as a supplemental Protocol and not a brand-new convention, was relatively speaking plain sailing for such an experienced body concerned with air safety. The right accommodations were struck and, as with all multilateral agreements, the result is a package acceptable to all concerned. After all, it is in the interest of all states from all geopolitical groups, whatever their sympathies for certain causes, to protect their own airports and aviation facilities and people, both citizens and foreigners, therein. Likewise, it is in their interest to have maximum protection for their own citizens when they travel abroad.

INTERNATIONAL MARITIME TERRORISM AND THE INTERNATIONAL MARITIME ORGANIZATION'S I 988 CONVENTION AND PROTOCOL

It is amazing that there has not been much more international maritime terrorism. The seizure of the cruise ship, the Achille Lauro, in 1985 highlighted in the world perception the problem. ${ }^{53}$ As with aircraft, ships, especially cruise liners engorged with multinational tourists, present a tempting target for those who wish to gain either fulfilled demands from target states or simply, but importantly to them, publicity for their cause especially from the world press and television. Cruise ships and any vessel of the merchant marine are vulnerable to terrorist attack, as they usually will be navigating solo and will not be heavily armed.

As with other areas of international personal security from terrorism, the loopholes have been larger than the actual coverage. Maritime transport as well as other transboundary territorial modes have been left aside. Only aviation has been dealt with because of the work of ICAO. The same comments made above about airport security can be made here. How stringent are the measures taken in the port state to vet baggage-handlers, porters, stewards, staff, crew, let alone passengers and friends and family wishing a "bon voyage"? The situation was clearly ripe for the taking. The facts of the Achille Lauro seizure would appear to demonstrate that a maritime hijacking was not the intent of the hijackers but rather that the vessel was only to be a means of their gaining entry as tourists to the Israeli port of

53 There have been other instances, such as the seizure in 1975 of the Suehiro Maru in Malsugat Bay in the Philippines by members of the Moro Liberation Front. See H. Stephens, "Maritime Terrorism and Piracy: Problems and Solutions in the Mid-r980s," in Y. Alexander (ed.), The rg86 Annual on Terrorism $165(1987)$. 
Ashdod to carry out terrorist action there. The discovery of their dubious status by a steward caused the take-over and subsequent events.

Whether one looks at this as an "accidental" or planned seizure, it makes little difference as the legal issues are the same. Lax security measures at the port of embarkation allowed the terrorists, under assumed names and with forged passports, to get on board. Whatever their ultimate intent, they in fact seized the cruise ship, murdered one passenger, Leon Klinghoffer, a United States citizen, and held many others hostage until their release.

Nevertheless, it was this incident, which within reason should have been quite predictable, that caused a flurry of rapid activity, ${ }^{54}$ by international standards. It is not the purpose of this article and space does not permit a recounting of the Achille Lauro facts; the key feature is simply that a group of persons took over a ship with people on board of various nationalities and held them hostage. Neither is it the purpose of this article to review whether the United States action in bringing down the Egyptian airplane that was carrying the hijackers to safety, was or was not in violation of international law. ${ }^{55}$

On March Io, I 988 the International Maritime Organization, a specialized agency of the United Nations, adopted two international instruments by consensus and not by a vote. As with the ICAO 1988 Protocol to the 197 I Montreal Convention, this adoption by consensus indicates that states were happy with the overall package deal. But it may be questioned whether the level of ambiguity that results from adoption by consensus is in the long term profitable. However, those who never try to climb never fall; so it is that in the attempt to curb the international cancer of terrorism we must grasp at any

54 See ibid., I 72, where the author states to the contrary that reactions to the Achille Lauro affair was "long on symbolism, but short on substance." However, this article was written before the adoption of the 1988 Rome Convention. At the stage of his writing, the IMO had only in I 986 adopted a nonbinding resolution expressing concern about maritime terrorism with the recommendation that states adopt more stringent security measures for passenger ships and their ports of call.

55 See e.g., on the Achille Lauro, G. Constantinople, "Towards a New Definition of Piracy: The Achille Lauro Incident," (1986) 26 Va. J. Int'l L. 723; J. McCredie, "Contemporary Issues of Force Against Terrorism: The United States Response to Achille Lauro - Questions of Jurisdiction and Its Exercise," ( 1986 ) i6 Ga. J. Int'l and Comp. L. 435; G. McGingley, "The Achille Lauro Affair: Implications for International Law," ( 1985 ) 52 Tenn. L. Rev. 691; and J. Paust, "Extradition and United States Prosecution of the Achille Lauro Hostage-Takers: Navigating the Hazards," (1987) 20 Vand. J. Int'1 L. 235 . 
potential method of doing so. These instruments are at least the foundation upon which, with increased international co-operation, an effective defence against terrorist violence may be built in the future.

In the case of maritime terrorism, the IMO for the first time had to deal with international criminal law and the questions of jurisdiction, extradition, and other manifold complications. The 1988 Rome Convention for the Suppression of Unlawful Acts Against the Safety of Maritime Navigation ${ }^{56}$ and the 1988 Protocol for the Suppression of Unlawful Acts Against the Safety of Fixed Platforms Located on the Continental Shelf ${ }^{57}$ go through the ambit of matters raised in the preceding ICAO Conventions, the Internationally Protected Persons Convention (IPP), the Hostages Convention, and the Nuclear Material Protection Convention.

As with the Hostages Convention, the Rome Convention addresses the progressive elimination of the root causes of terrorism in the preamble but has no actual article in the Convention itself that deals with that matter, including colonialism, racism and other flagrant forms of alien domination, and violations of human rights. Neither is there a covering restriction reaffirming the legitimacy of self-determination units to use force towards that end as occurred with the IPP Convention. ${ }^{58}$ An attempt was made by Libya to have an article included that would, like Article 12 of the Hostages Convention, state that the Convention would not apply to situations covered by the laws of armed conflict. However, it was not accepted since on a factual basis offences under the Rome Convention would not have parallels in the Geneva Conventions and Protocols.

The Council of the IMO decided in June 1987 , in accordance with Article 2 (b) of the Convention on the International Maritime Organization, ${ }^{59}$ to convene an international conference on the suppression of unlawful acts against the safety of maritime navigation. The Assembly of the Organization endorsed this decision at its fifteenth regular session by resolution A.633 (I 5 ) of November 20, $1987 .{ }^{60}$ The intended purpose of the proposed conference was to consider the adoption of treaties on terrorist acts against maritime navigation and fixed platforms on the continental shelf.

${ }^{38}$ IMO Doc. SUA/CONF/15, Mar. 10, 1988.

${ }^{57}$ IMO Doc. SUA/CONF/16, Mar. 10, 1988.

58 UNGA Res. 3166 (XXVIII), Sept. 14, 1973.

${ }^{59}$ IMO Doc. SUA/CONF/WP. I, Mar. 9, 1988, at I.

so Ibid. 
The conference was convened in Italy in March 1988 . Seventysix states participated in the Conference. ${ }^{61}$ These states represented a wide cross-section of member states of the United Nations; it was not the case (and the same is true at ICAO) that only "victim" states of international terrorism were represented. Not only were the Western Europeans, Canada, Israel, Japan, and the United States present, but also among others the socialist states of Eastern Europe, Arab and African states and specifically Algeria, the Islamic Republic of Iran, Iraq, Lebanon, Libyan Arab Jamahiria, and the Syrian Arab Republic. The Palestine Liberation Organization (PLO) also sent observers to the Conference.

The draft treaty texts were prepared by the Ad Hoc Preparatory Committee, which had been established by the IMO Council. This Committee had used as the basis of its drafts an initial text prepared by Austria, Egypt, and Italy. ${ }^{62}$ The aim of the draft convention was clearly to fill the gap regarding suppression of acts of terrorism related to maritime traffic. Until the adoption of the I 988 Rome Convention and Protocol, the only possible coverage was from a strictly maritime perspective by reference to Article 15 of the Geneva Convention on the High Seas, $1958{ }^{63}$ and Article 101 of the 1982 Montego Bay Convention on the Law of the Sea ${ }^{64}$ concerning acts of piracy under the law of nations. These articles are not particularly apt. They deal with acts of violence committed for private ends by the crew or passengers of a private ship on the high seas against another ship or persons thereon. These articles, therefore, clearly only relate to a small number of international criminal acts committed for private ends and also with two vessels being involved. Even though some would suggest ${ }^{65}$ that these articles do not rule out piracy defined more liberally in accordance with the norms of customary international law, and that maritime hijackings as in the case of the Achille Lauro are customary law international crimes, this would not be that profitable from a treaty law reference point of view. Even if it were accepted, and this is by no means certain, that acts of piracy do encompass such scenarios, the only effect would be to declare the perpetra-

61 Ibid., I-2.

62 IMO Doc. PCUA 2/2. See IMO Doc. PCUA 2/5, June 2, 1987, at 2 and IMO Doc. PCUA 1/3, Feb. 3 , 1987, at 1 .

${ }^{63} 450$ UNTS 82.

84 Third UN Conference on the Law of the Sea, Off. Rec., Vol. XVII, at I 39; reprinted in (1982) 21 Int'l Leg. Mat. 1245.

os Supra note 55 . 
tors hostis humanis and allow potentially for universal jurisdiction. However, no provision of aut dedere, aut judicare would apply. It should be added that the 1979 United Nations Convention on the Taking of Hostages would apply in all probability to cases of maritime hijackings, with reference to the persons held rather than to the maritime locus. However, on closer inspection there are problems in this line of argument. Article I ( $I$ ) of the 1979 Convention bases the offence of hostage-taking upon the aim of compelling a third party to do or to abstain from doing any act as an explicit or implicit condition of releasing the person/s held hostage. Should a case of maritime hijacking occur for publicity for a cause rather than targetting a particular state or other third party, the 1979 Convention would not apply.

The I 988 Rome Convention reads generally like the earlier international conventions. The IMO was able to model the offences on those delineated with respect to aircraft in the Hague and Montreal conventions. The aim is emphatically to suppress in a comprehensive fashion unlawful acts against maritime navigation that endanger innocent human lives, put in jeopardy the safety of persons and property, and affect seriously the operation of maritime services. Such acts are of grave concern not only to involved states but to the wellbeing of humanity as a whole.

For the purposes of this Convention, a "ship" means a vessel of any type tilat is not attached permanently to the seabed, including dynamically supported craft, submersibles, and other floating craft. Initially, at the second session of the Ad Hoc Preparatory Commission, although there was general support for the definition of "ship" in Article I, there was some question as to the phrase "dynamically supported craft." It was recalled that at the first session this term was chosen as it was more modern and comprehensive than the alternative "hydrofoil boats and air-cushion vehicles" that was placed in the original draft. ${ }^{66} \mathrm{It}$ is interesting to note that Article 2 lists the types of vessels, such as warships, that the Convention does not apply to. It would seem that this exemption was included so as not to prejudice the immunities under customary and conventional international law accorded to ships owned and operated by states for non-commercial purposes. $^{67}$

66 IMO Doc. PCUA 2/5, June 2, 1987 , at 4 .

67 See Rome Convention 1988, Art. 2 (2) and IMO Doc. PCUA 2/5 at 7. 
Article 3(I) provided for the definition of the offence. Offences are committed by any person who unlawfully and intentionally seizes or exercises control over a ship by force or by threat of force or any other force of intimidation; or who performs an act of violence against a person or aboard a ship if that act is likely to endanger the safe navigation of that ship; or who places or causes to be placed on a ship, by any means, devices or substances likely to destroy the ship or cause damage to the vessel or its cargo; or which endangers or is likely to endanger the safe navigation of the ship; or who destroys or seriously damages maritime navigational facilities or seriously interferes with their operation, if such is likely to endanger the safe navigation of the ship; or who communicates information known by him or her to be false and thereby endangers the safe navigation of the ship; or who injures or kills anyone in connection with the commission or the attempted commission of any of the offences so far mentioned.

It is only this latter offence that strikes a new note and goes beyond analogies to the Hague and Montreal conventions. It would deal with the situation faced in the Achille Lauro when Leon Klinghoffer, an American citizen, was murdered. Some delegations ${ }^{68}$ wished it deleted from the draft. Other delegations considered it to be an aggravating provision and not a separate substantive offence, and wished it to be put in a separate paragraph. ${ }^{69}$ Still others considered that the killing of persons in the course of unlawful acts against on-board maritime vessels was fundamental and needed to be specifically addressed as a separate offence. ${ }^{70}$ The latter view prevailed. Thus, it is only the Rome Convention along with the IPP Convention that makes it a criminal offence to kill or injure a person. Neither the civil aviation conventions nor the Hostages Convention do so. To have failed to have included it would have been a glaring omission, as it is in these other treaties. As it stands, inclusion in the list of offences brings into play the aut dedere, aut judicare principle.

Article 3 (2) provides for attempts, abetting the commission of an offence, or being an accomplice and threatening, with or without a condition, to compel a person, whether juridical or physical, to do or to refrain from doing any act, to commit any of the aforegoing offences, if that threat is likely to endanger the safe navigation of the ship in question.

68 Ad Hoc Preparatory Committee, Ist Sess. Agenda item 4, IMO Doc. PCUA/ 14, Mar. 16, 1987, para. 30.

60 Ibid.

70 Ibid. 
At the second session of the Ad Hoc Preparatory Commission, the Kuwaiti delegation proposed the inclusion of an application of the provisions of Article 3 to a person who commits an offence on behalf of a government. Kuwait explained this proposal as an attempt to suppress politically motivated unlawful acts constituting an outrage to humanity, regardless of the status of the perpetrators. ${ }^{11}$ This basic principle was already contained and is contained in the preamble to the Rome Convention as adopted which refers to the unequivocal condemnation of all acts of terrorism wherever and by whomever committed and recalls General Assembly resolution 40/6 I of December 9,1985 .

Many delegations agreed at this stage with the Kuwaiti delegation, based on the fact that the Rome Convention was intended to apply to all types of international maritime terrorism, regardless of who the offender might be. ${ }^{72}$ However, it was felt that such an inclusion was not necessary as Article 3 applies to "any person" and therefore does not regard status as a defence. In this regard the sinking of the Greenpeace vessel, the Rainbow Warrior, in Auckland, New Zealand, by agents of the French government is on point. In its first session the Ad Hoc Preparatory Committee ${ }^{73}$ had discussed an earlier proposal ${ }^{74}$ for the inclusion of a new paragraph that would cover situations where the naval forces of a state or other ship flying its flag which is under the direct instruction of that state committed the offences. Doubt was expressed by some delegations as to the feasibility of such an article, as the whole ambit of the Convention was geared towards offences committed by individuals and any attempt to include states in the rationa personae of the Convention would raise fundamental difficulties. No such provision appears in the Convention.

The international element that brings an offence into the realm of the proscription by international law is contained in Article 4 (I). It provides that the Convention is to apply if the ship in question is navigating or is scheduled to navigate into, through, or from waters beyond the outer limit of the territorial sea of a single state, or the lateral maritime limits of its territorial sea with adjacent states. Some delegations at the Conference were in favour of also including straits used for international navigation but other delegations were of the view that this was unnecessary as straits were already envisaged in

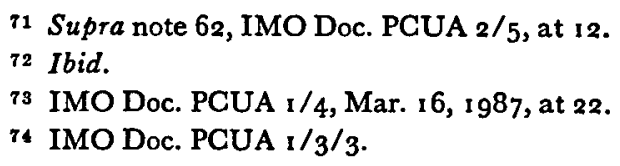


Article 4(I). Thus, the Convention will apply to these straits, without prejudice to the legal status of the waters forming them in accordance with the relevant rules of customary and conventional international law. ${ }^{75}$

Article 5 stipulates that each state party shall make the offences punishable "by appropriate penalties that take into account the grave nature of the said offences." This convention relies upon the fragile shield of fulfilment of treaty obligations in good faith, pacta sunt servanda, as do the other conventions.

From the jurisdictional perspective, Article 6 follows the now standard pattern of utilization of the territorial, active, and passive nationality, ${ }^{76}$ and presence within the state principles. Similar to Article 5 (3) of the Hostages Convention, it does not exclude any criminal jurisdiction exercised in accordance with international law. It includes also the provision that was novel to the 1979 Convention $^{77}$ in that it provides for jurisdiction to be taken also by states where the offender is a stateless person who has his or her habitual residence in that state or by a state that is the target of any attempt to compel an act to be done or abstention from so doing. However, the bases of jurisdiction are divided into two categories. First, Article 6(I) provides that states parties shall establish their jurisdiction on the bases of nationality of the flag state; and on the territorial principle and the nationality of the offender. Article $6(4)$ mandates jurisdiction on presence of the offender. Article 6(2) follows with other optional bases that states may also utilize: states where stateless persons are habitually resident, the passive nationality basis, and target state basis.

Some controversial issues have been raised with respect to some of these bases. Concerning the use of presence within the territory, it has been argued that this should not be applied to nationals of a nonparty state. ${ }^{78}$ However, others have responded by arguing that to limit the conventions in this way is to undermine their effectiveness in combatting terrorism. ${ }^{79} \mathrm{It}$ is submitted that this is the correct view.

75 IMO Doc. SUA/CONF./WP. I, Mar. 9, 1988 , at 6.

78 Supra, note 56 , Art. 5 .

77 See Art. 6(5).

$78 \mathrm{~J}$. Paust, supra note 55, at 254, with respect to the same provision in the Hostages Convention.

70 M. Halberstam, "Terrorism on the High Seas: The Achille Lauro, Piracy and the IMO Convention on Maritime Safety," (1988) 82 Am. J. Int'l L. 269, at 27 . See also ibid., where the author argues further that terrorism is subject to universal jurisdiction under customary international law and that the conventions "create customary international law." 
To disallow jurisdiction over the offence in such circumstances would be to eviscerate the potential of the conventions; it would be the ultimate in third party frustration.

Concerning the passive nationality principle and the target state principle, opposition was expressed during the deliberations of the Ad Hoc Preparatory Committee. The concern with regard to the passive nationality principle was that it would result in too many states claiming jurisdiction. ${ }^{80}$

Regarding the target state basis, it was suggested that it was unnecessary, as this will be co-terminous with the flag state. ${ }^{81}$ It was stressed by other states that both bases were necessary to ensure maximum potential for prosecution and that it would be better to have too many states able to prosecute than none. However, votes taken at that stage indicated overwhelming support for the passive nationality basis and substantial but slightly lesser support for the target state principle. ${ }^{\mathbf{2}}$ Therefore both were included in the final product.

Article 9 provides that nothing in this Convention of 1988 shall affect in any way the rules of international law pertaining to the competence of states to exercise investigative or enforcement jurisdiction on board ships not flying their flag. This clearly deals with the right of visit by warships on the high seas ${ }^{83}$ and the search and arrest of foreign flag vessels in a state's territorial sea and lately in its exclusive economic zone and in the waters above its continental shelf for violations of the laws that appertain to those zones. ${ }^{84}$

Article Io is yet another classic example of the principle of aut dedere, aut judicare. The Convention does not provide absolutely for extradition at all costs, but rather for extradition or the submission of the case to the state's competent authorities for the purpose of prosecution, in accordance with the laws of that state. This is to be done without exception whatsoever. Clearly, as with the other conventions, this may be open to abuse. It does not read "extradite or prosecute." Obviously it is open to prosecutorial discretion in the holding state. The hope is that in fulfilment of its obligations a state's prosecutorial

80 Ibid., 296. Note that the Restatement (Third) of Foreign Relations Law of the United States ( 1987 ), s. 402, provides that although not generally accepted for all crimes, it has been increasingly used concerning terrorist acts.

81 Ibid.

82 See Halberstam, supra note 79 , at 296 citing IMO Doc. PGUA 2/5, at 18, June 2, 1987, para. 89 .

83 See supra note 64, Art. I 10.

84 Ibid., Art. 11 I (2). 
authorities will exercise that mandate in good faith. As with The Netherlands' proposal at ICAO ${ }^{85}$ some delegations at the IMO would appear to interpret this to mean that the obligation to submit for prosecution in one's own state only arises where an extradition request is made and refused. ${ }^{86}$

Article II (I) indicates that the offences contained in the Convention will be deemed to be included in any existing bilateral treaties between the parties. They undertake to include these offences as extraditable offences in any future treaty. Article I I (2) makes the usual stipulation that where a state makes a treaty a prerequisite for extradition, it "may, at its option" consider the Convention as a legal basis for extradition of the offences contained in the Convention. Unlike the 1988 Protocol to the Montreal Convention, extradition is not restricted to the state where the offence was committed. Article I I (4) provides that if it is necessary, the listed offences shall be treated for the purposes of extradition, as if they had been committed in a place within the jurisdiction of the state party making the request and not only in the place where they actually occurred. Paragraph 5 of Article I I indicates that where the requested state party receives more than one extradition request from states that have established jurisdiction and decides not to prosecute itself, then it shall pay due regard to the interests and responsibilities of the state party whose flag the ship was flying at the time of the offence. It is not clear what this latter provision actually means. One commentator has stated that if it simply means that the interests of the flag state should be considered, this is already provided for as that state may request extradition. On this basis the provision is redundant. If it has a deeper meaning, it is difficult to see what it is. ${ }^{87}$

This Convention, as with its predecessors, does not actually speak of terrorism and does not provide for political motivation to act as a bar to extradition. Clearly the aut dedere, aut judicare provision in Article ro( $I$ ) endeavours to cover the situation by providing for submission to a state's own prosecutorial authorities, if extradition is refused. This would be applicable should the refusal be based on such

85 Supra note 44.

86 See Halberstam, supra note 79, at 297. Note R. Rosenstock, "International Convention Against the Taking of Hostages: Another Community Step Against Terrorism," ( 1980 ) 9 Den. J. Int'l L. and Pol, 169, at I8 1 , where he argues that, based on the legislative history of that Convention, there is no doubt that prosecution is not dependent upon an extradition request.

87 Halberstam, ibid., 303. 
exception. Article Io(2) provides that the accused shall be guaranteed fair treatment and be accorded all the rights provided for by the law of the state in which he or she is present.

At the first session of the Ad Hoc Preparatory Committee, ${ }^{88}$ a later-removed Article I 3 was considered. It was intended to safeguard existing treaties on asylum. Two alternatives were suggested: first, that the provisions of the Convention should not affect any conventional obligations on diplomatic asylum in force at the date of adoption of the Convention, as between states bound by such obligations; second, that the Convention should not affect the application of any conventional obligations on asylum. Objections were raised as to the first proposal dealing with diplomatic asylum. As to the second alternative, although some felt this to be basically acceptable many delegations considered it unnecessary based on the last paragraph of the preamble, which in the Convention as adopted reads "Recognizing the need for all states, in combatting unlawful acts against the safety of maritime navigation, strictly to comply with the principles of general international law." Draft Article I 3 on asylum was deleted from the text.

The remaining articles of the Convention of note deal with mutual assistance in connection with this type of criminal offence. ${ }^{89}$ States parties are obliged ${ }^{30}$ to afford assistance with criminal proceedings, including obtaining evidence at their disposal, in conformity with any treaties on mutual assistance that may be in existence between them. ${ }^{91}$ In the absence of such bilateral treaties, they shall afford each other assistance in accordance with national law.

As well as such assistance the important obligation is included to co-operate to prevent any of the offences from occurring, first in particular by taking all practicable measures to prevent preparations in the territory of a state party for the commission of the Convention offences either within or without that state. ${ }^{92}$ Second, they shall co-operate by exchanging information in accordance with domestic law and co-ordinate administrative and other measures as are appro-

88 Supra note 73, at 22.

89 Arts. 12-14.

80 Art. 12 (1).

91 E.g., see the 1985 Treaty between Canada and the United States on Mutual Assistance in Criminal Matters, not yet in force, reprinted in ( I 985) 24 Int'l Leg. Mat. 1092. Note also the European Convention on Mutual Assistance in Criminal Matters, I 959 Eur. T.S. No. 30.

92 Art. 13(1)(a). 
priate to prevent the commission of offences. ${ }^{93}$ Again, these provisions are modelled on the Hostages Convention. ${ }^{94}$

Article I 3 (2) provides for the duty to exercise "all possible efforts" to avoid unduly detaining or delaying a ship whose passage has been delayed or interrupted by the commission of an offence and in whose territory the ship, passengers, or crew are present. It is reminiscent of Article 9(2) of the 1970 Hague Convention for the Suppression of Unlawful Seizure of Aircraft, which similarly states that where the aircraft or its passengers and crew are present, contracting states shall facilitate the continuation of the journey of the crew and passengers as soon as is practicable and shall without delay return the aircraft and cargo to those persons lawfully entitled to possession.

Should a state party have reason to believe that a Convention offence will be committed, it is obliged by Article 14 to furnish as promptly as possible, in accordance with its national law, any relevant information that it possesses to those states which it believes would be the states with jurisdiction over the potential offence. ${ }^{95}$

It should be remembered that Article i 4 of the Hostages Convention contained an "anti-Entebbe" clause, that stated that nothing in that Convention should be interpreted as justification for the violation of the territorial integrity or political independence of a state in contravention of the United Nations Charter. During the debate at the IMO the issue resurfaced. Recent events such as the United States bombing raids on Libya and the interception of the Egyptian aircraft following the Achille Lauro seizure obviously prompted this. At the first session of the Ad Hoc Preparatory Committee, the USSR proposed that in combatting maritime terrorism, states should act in compliance with international law and illegal acts undertaken to combat such terrorism be inadmissible. ${ }^{96}$ The provision was not put into the Convention proper, but reference in part is made in the preamble.

As with the other international conventions on the various aspects of international terrorism, any disputes between contracting states concerning the interpretation and application of the Convention that cannot be settled within a reasonable time by negotiation shall at the request of one of the states be submitted to arbitration. If after six

\footnotetext{
93 Art. 13(1) (b).

24 See Arts. 4(a) and (b).

95 See also Art. 12 of the Montreal Convention.

96 IMO Doc. PCUA 1/WP. I 7, Mar. 5, 1987.
} 
months from this request for arbitration the parties cannot agree on the organization of the arbitration, any one of the parties may refer the dispute to the International Court of Justice by request. ${ }^{97}$ Reservations as to the dispute settlement mechanisms are allowed. ${ }^{98}$

This Convention will enter into force ninety days after the date on which fifteen states have signed it without reservation as to ratification, accession, or approval, or have deposited an instrument of ratification, acceptance, approval, or accession. ${ }^{89}$

The adoption of the Convention does not rule out the imperative of reducing the vulnerability of maritime vessels as well as ports themselves to terrorist attack. Clearly, one of the first safeguards is to train personnel for such trouble and to increase security measures.

At the same conference in Rome, the IMO also adopted a Protocol to the Rome Convention. This Protocol, of March io, I988, concerns the Suppression of Unlawful Acts Against the Safety of Fixed Platforms Located on the Continental Shelf. ${ }^{100}$ As with the Protocol to the Montreal Convention, this Protocol is open only to states parties to the main Convention. ${ }^{101}$ The IMO in adopting this Protocol, the draft of which was prepared by the Ad Hoc Preparatory Committee, ${ }^{102}$ recognized that the reasons behind the Rome Convention apply also to fixed platforms on the continental shelf. The provisions contained in Articles 5, 7, and 10 to 16 of the Rome Convention apply mutatis mutandis to the offences set out in the Protocol, where they are committed on board or against fixed platforms on the continental shelf. ${ }^{103}$ In those cases where the Protocol does not apply on this basis, it nevertheless applies when the offender or the alleged offender is found in the territory of a state party other than the state in whose internal waters or territorial sea the fixed platform is located. ${ }^{104}$

For the purposes of the Protocol, a "fixed platform" is defined as an "artificial island, installation or structure permanently attached to the sea-bed for the purpose of exploration or exploitation of resources

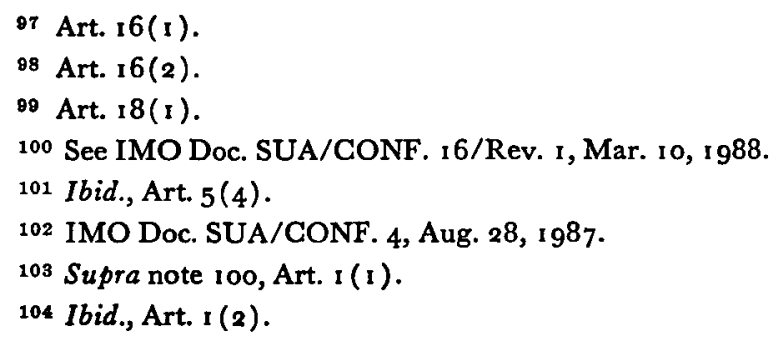


or for other economic purposes." ${ }^{105}$ Article 2(I) states that it is an offence if a person unlawfully and intentionally by force or threat of force or any other form of intimidation seizes or exercises control of such a platform; performs a violent act against a person on board a fixed platform if that act is likely to endanger its safety; destroys a fixed platform or causes damage to it which again is likely to endanger its safety; or places or causes to be placed on a fixed platform, by any means whatsoever, a device or substance which is likely to destroy that fixed platform or endanger its safety or injures or kills any person in connection with the commission or attempted commission of any of the offences. Article 2(2) provides for attempts, abetting the commission of any such offence, being an accomplice, and threatening to commit any of the offences if that threat is likely to endanger the safety of the fixed platform. Article 3 indicates the jurisdictional bases, which are basically the same as those in Article 6 of the Rome Convention. The only difference is to be found in Article 3 ( I) (a), which obliges states to take the necessary measures to establish jurisdiction over the offences set forth in Article 2 when the offence is committed against or on board a fixed platform while it is located on the continental shelf.

At the second session of the Ad Hoc Committee in 1987 some delegations questioned whether a basis of jurisdiction should exist in respect of offences committed against or on board a fixed platform operated by a commercial firm which has its principal place of business in the state in question. ${ }^{106}$ In fact such a provision had existed in an earlier draft. ${ }^{107}$ It was pointed out by these delegations that since platforms do not fly a national flag, there was a close link between the commercial firms operating such platforms and the state where the firms have their place of business. Such states, it was argued, had an interest in protecting these platforms. ${ }^{108}$ Other delegations could not accept this. ${ }^{109}$ Their view was that extraterritorial jurisdiction could not be given to states on purely economic grounds. ${ }^{110}$ Clearly this was a matter of high principle. The result was that such a provision was not included in the final text.

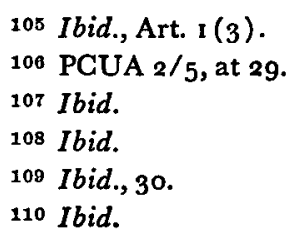


Article 4 reinforces the rules of international maritime law by stating that the Protocol shall not affect in any way such rules pertaining to fixed platforms on the continental shelf. Article 4 of the draft Protocol prepared by the Ad Hoc Preparatory Committee stated more specifically that the Protocol would not alter the existing international rules concerning the competence of states to exercise investigative or enforcement jurisdiction on fixed platforms located on their continental shelves. ${ }^{111}$

The Protocol will enter into force ninety days following the date upon which three states have signed it without reservation as to ratification, acceptance, or approval or have ratified, accepted, approved, or acceded to it. The Protocol will not enter into force before the Rome Convention itself is in force. ${ }^{112}$

\section{Conclusions}

These efforts at filling the gaps presented by new modes of international terrorism are to be lauded. Canada played an active part in the adoption by consensus of all three agreements and, it is expected, will ratify them once the requisite Criminal Code amendments are in place to provide for extraterritorial jurisdiction over the offences and presence of the accused within Canada being sufficient to provide for prosecution in Canada.

It is again emphasized, however, that conventions will be toothless paper tigers if they are frustrated by non-parties or if obligations are not fulfilled in good faith. States should be encouraged at every opportunity not to thwart the efficacy of the deterrent value of these conventions. States should also be encouraged to increase security measures and to co-operate to the greatest extent possible in exchanging information and evidence not only for the purpose of prosecution after the event, but most importantly to prevent it from occurring.

111 Supra note 62, at 3 .

112 Supra note 100, Art. 6(1). 
Sommaire

Le droit international et le terrorisme: des problèmes séculaires, des objectifs différents

Le terrorisme ne connaît pas de frontières. $A$ la lumière de plusieurs incidents récents (les attaques aux aéroports de Rome, Vienne et de Francfort, la saisie du paquebot Achille Lauro en 1985 et l'explosion à bord le vol Pan-Am 103 en Ecosse en 1988) on se rend compte que beaucoup reste à faire pour mettre fin à ce fiéau.

Cet article traite des questions suivantes: (I) est-ce que l'enlèvement des causes de ce fléau doit avoir préséance sur l'adoption de nouvelles conventions; (2) quelles sont les lacunes dans le réseau de conventions multilatérales existantes et (3) les mesures adoptées récemment par l'OACI et par l'OMI pour rémédier à la situation seront-elles éfficaces? 